\title{
Sport for Development in International Relations
}

\author{
ARNOŠT SVOBODA AND SIMONA ŠAFAŘíKOVÁ
}

\section{sciendo}

Politics in Central Europe (ISSN: 1801-3422)

Vol. 17, No. 3

DOI: 10.2478/pce-2021-0020

\begin{abstract}
This article introduces the concept of sport for development and peace both as a theoretical notion and a part of the political-economical practice. Together with a brief definition and a historical overview, the main goal is to present the sport and development in the context of international relations, a network of stakeholders, practical implementation within major projects and its progressive inclusion into the development documents and strategies. Specifically, the article highlights the adoption of the concept by two major institutions, the United Nations and the International Olympic Committee as formal umbrella organisations. Furthermore, the role of the sport for development within the UN's agenda of Sustainable Development Goals is elaborated. Since the topic is a frequent object of academic research and critical analysis, the article concludes with an outline of the commonly mentioned contested topics and critical debates which permeate both academic production and activities of international state and non-governmental organisations.
\end{abstract}

Keywords: sport for development, sustainable development goals, United Nations

\section{Introduction}

A concept sometimes referred to as sport for development, sport for development and peace, sport for good or sport for social change, has become popular in the last 25 years. Despite many academic endeavours, it remains a contested field with interesting debates where sport and international development agenda overlap. In this paper, our goal is to introduce the sport for development and peace as a multifaceted concept with a long history where, possibly under different labels, the sport was gaining significance not only as a popular leisure activity but also as an easily accessible tool for dealing with numerous 
difficult issues and areas in the societies. At the same time, the popularity of sport and its incorporation into the development field attracted the attention of international organisations.

First, we will briefly elaborate on the definition of sport for development and peace concept. Then, we will give an overview of the process of incorporation into the agenda of international organisations and activities of various actors and describe the concept's place in major development documents. Specifically, the link between sport for development and the United Nations' articulation of sustainable development goals will be discussed. Finally, we will mention several critical remarks on sport for development as they are discussed in recent academic literature.

\section{Sport for Development - conceptual framework}

The very basic concept of sport for development (SFD) or sport for development and peace (SDP) has already been defined by several authors but none of the definitions have reached a final academic consensus. All the definitions talk about the fact that sport might also bring about positive results in the non-sportive domain which is the core of the sport for development initiatives. Millington and Kidd (2019: 13) define 'sport for good' as a 'sport initiated, organized and played for social purpose'. Lyras and Welty Peachey (2011: 311) define sport for development as'the use of sport to exert a positive influence on public health, the socialisation of children, youths and adults, the social inclusion of the disadvantaged, the economic development of regions and states, and on fostering intercultural exchange and conflict resolution'. Guilianotti (2011: 208) conceptualises 'sport for development as a socio-cultural tool to reduce social tensions and promote reconciliation and reconstruction, notably in post-conflict contexts'. All these definitions say that sport might be used for different non-sporting objectives. Those range from conflict resolution, gender equity, disease prevention, social values learning, tackling poverty, fighting racism to combating violence, drug abuse or disaster response (Coalter 2010; Giulianotti 2011; Kidd 2008).

On the theoretical level and as an integrated concept, initiatives under the label of sport for development are a relatively new phenomenon proliferating in the last three decades. Yet, using sport as a tool for social, economic, political or moral goals dates back to previous centuries (Darnell et al. 2019). Amongst other instances, it was used in antiquity in ancient Greece during the Olympic Games. The Olympic truce was a symbol of peace and in this period of history, the wars were stopped during the organisation of the antic Olympic Games. Also, sport and physical activities were connected to personal and social transformation at that time (Millington - Kidd 2019). According to Giulianotti, sport also played a role in colonial dominance from the eighteenth century onward. By 
contrast, as of the mid-twentieth century, sport often stood in the centre of the post-colonial struggles of developing countries striving for independence from the former colonial powers. Additionally, the United Nations (UN) included it in the reconstruction process in Europe after the Second World War and, as we will describe later, it played a role during the Cold War. From the mid-1990s, a specific sport for development agenda has proliferated under various actors: transnational corporations, governmental and non-governmental organisations (NGOs) and new social movements (Giulianotti 2011).

Furthermore, various high-profile politicians publicly supported SDP, such as Kofi Annan, the former UN Secretary-General: 'It has an almost unmatched role to play in promoting understanding, healing wounds, mobilising support for social causes, and breaking down barriers' (Kofi Annan Foundation 2010), or South African political leader, Nelson Mandela:

Sport has the power to change the world. It has the power to inspire. It has the power to unite people in a way that little else does. It speaks to youth in a language they understand. Sport can create hope where once there was only despair. It is more powerful than the government in breaking down racial barriers (in Busbee 2013).

Slowly, sport for development has become part of foreign relations policies of the Global North countries within the so-called development cooperation agenda and, subsequently, it also appeared to be institutionalised within the international development agenda. In the late 1990s, it was regarded as a new engine for development, different from the previous orthodox development policies of the 1970s and 1980s that were considered to have failed (Levermore 2008; Millington - Kidd 2019). Sport was perceived as a non-political field that is not associated with corruption in the international development sector. The new millennium saw a huge increase in the number of sport for development initiatives, projects, programs and collaborations. In general, many of the involved actors currently operate in cooperation and, thus, might form alliances that would be hardly thinkable outside the SDP discourse. Yet, only sometimes are such relationships balanced; they range from truly collaborative activities to projects dominantly led by state officials or by powerful international non-state donors (Levermore - Beacom 2009; Lindsey et al. 2020). As a complex result of the above-mentioned processes, and in the context of the neoliberal order, the popularity of programmes using sport as a development tool rose. The positive contribution of sport to opening ways to improve an individual's life has been widely acknowledged, especially in connection with social capital and community development (Darnell et al. 2019).

From a broader perspective, sport for development can be regarded as a tool usable by many actors, in different contexts and for different purposes. Even 
though not traditionally recognised as a part of the SDP agenda, capitalising on sport by states or political regimes presents another example of how sports events enter the field of international politics. Besides well-known occurrences such as boycotts of the Olympic Games in Moscow 1980 and Los Angeles 1984, there is a long tradition of utilising sport for enhancing the international image or status of a specific country. This is sometimes referred to as soft power as opposed to hard power involving military or economic capacities (Nye 2004). Mostly it is linked to the hosting of sport mega-events or, as in the case of Cuba, sending athletes or coaches to developing countries (Darnell - Huish 2015; Darnell et al. 2019). Apart from highlighting a nation's culture, politics, credibility and potential for agency outwards, the soft power can also bolster national identity (Grix - Lee 2013). Since sport is generally publicly perceived as a positive and unproblematic value, even its presentation under a specific national flag most likely reinforces the nation's international capital.

\section{Institutionalisation of SFD: international relations and development documents}

The beginning of the process of institutionalisation dates back to 1978. The International Charter of Physical Education and Sport (UNESCO 2015) is widely regarded as an initial document for the institutional connection between sport and development. Most notably, the document mentions sport as an important agent in learning values of fair play, equality, commitment, courage, teamwork or respect for rules and laws. Simultaneously, sport is acclaimed there as a fundamental right for all. The Convention on the Rights of the Child (UN General Assembly 1989) recognises that children worldwide should have the right 'to rest and leisure and to engage in play and recreational activities' (UNICEF 1989, art. 31). This should be guaranteed by each state. In 2006, another important international document that mentions sport as a vital tool was adopted by the UN. It was the Convention on the Rights of Persons with Disabilities (CRPD). Its article 30 ( $5 \mathrm{a}, \mathrm{b}, \mathrm{c}, \mathrm{d}, \mathrm{e})$ focuses on sport saying that state parties shall promote sporting activities and ensure that people with disabilities have access to sporting opportunities. As depicted by the aforementioned documents, the UN has been the main motor behind the advancing inclusion of sport and physical activities into international development documents and on its agenda. On the other hand, Darnell et al. (2019) and Levermore (2009) argue that one of the reasons for the rising institutionalisation of SDP is its compatibility with basic neoliberal theses such as better employment, bolstering life skills, improving infrastructure, extensive trade and international investments or effective governance.

Regarding the inclusion of SDP into formal institutions, the ground-breaking year was 2001 when the United Nations Office for Sport and Development and 
Peace (UNOSDP) was established. Hence, the UN became a leading actor in the coordination of SDP initiatives. At the same time, a link between sport and development gets a firmer position in UN policy documents. The international community is called to acknowledge and support the role of sport as a means to achieve not only the formal development goals (Millennium Development Goals and, subsequently, Sustainable Development Goals), but also a general set of development and peace-oriented aims (UN General Assembly 2003). The SDP agenda was further supported by a high-level conference in Swiss Magglingen in 2003 (co-organised by UNOSDP), where sport and development organisations formally met for the first time including governments' representatives, sports federations, UN offices and corporate and civil sector representatives (Darnell et al. 2019). In 2005, the conference was held for the second time (ICSSPE 2005) but, more importantly, the UN declared 2005 as the International Year of Sport and Physical Education. Amongst its aims, there was also the support of sport for all and enhancing the role of sport in reaching the development goals as well as mainstreaming sport into governmental development policies (United Nations 2006). With the foundation of UNOSDP, a special United Nations Inter-agency Task Force on Sport for Development and Peace was created in the same year to advance the knowledge in the area of sport for development, to review current SDP initiatives and to prepare recommendations for the SDP field. Its report Sport for Development and Peace: Towards Achieving the Millennium Development Goals can be seen as the first document connecting sport with the Millennium Development Goals (MDGs) agenda. In 2014, Ban Ki-moon, the then UN Secretary-General, declared 6 April as the International Day of SDP to highlight and celebrate sports' development potential (Harrison - Boehmer 2019).

As Darnell et al. (2019) further mention, one of the longest-standing players in the SDP field is the Commonwealth group of nations, namely for its activist approach to utilising sport for affecting specific topics on the international scene. Employing the symbolic significance of sport, the Commonwealth reflected on the politics of apartheid in South Africa with pressure on sporting isolation of the country up to 1991. Another important step in forming the international SDP movement was the establishment of the Commonwealth Committee on Cooperation through Sport in 1991. Later on, it was succeeded by the Commonwealth Advisory Body on Sport in 2004 bringing together different governments and organisations. SDP, as a proclaimed policy, was included in Commonwealth official documents in 2013 (e.g. Kay - Dudfield 2013). Darnell et al. (2019) summed up by saying that the strong position of sport in the Commonwealth group of nations is preceded by its important role in the former British empire and the colonial past. All the more, the Commonwealth Secretariat was the main organiser of the report entitled Sport for Development and Peace and the 2030 Agenda for Sustainable Development that connects sport with selected Sustainable Development Goals (SDG, see later). 
Following the parallels in underscoring social and cultural benefits of sport between the UN and the International Olympic Committee (IOC), it was only a question of time when the IOC became more active in the SDP field. The link to 'sport for good' is even clearer here compared to the UN or other organisations because of the primary focus of the IOC and its use of symbols such as the Olympic truce (IOC 2015) or the Olympic rings (IOC 2019). Furthermore, specific initiatives, such as the OlympAfrica Foundation founded in 1989 (Sport en Commun n.d.), led to the establishment of the IOC as one of the key players in the SDP field working in a close relationship with the UN. Finally, when the UN announced the closure of UNOSDP in 2017 (Guilianotti 2019; sportanddev. org 2017), the IOC was widely recognised as an umbrella organisation for international SDP activities. The operations of the Commission for Public Affairs and Social Development through Sport follow up with the general scope of work of the former UNOSDP (IOC 2020). As Darnell et al. (2019) observe, several critical remarks have emerged in the last years pointing out the IOC's primary focus on the high-performance sport, the lack of experience in non-sporting sectors, reinforcing the status-quo of the powerful Global North or under-resourced national Olympic committees from Global South countries being urged to follow the development agenda without appropriate funding or experience. Handing over the responsibilities for SDP to the IOC left a vacuum within the UN sector (Giulianotti 2019). Currently, mentions of SDP on the UN main website, including the information that has been gathered within the last 20 years about the field, are rather scattered. Most of the materials have been integrated into the Department of Economic and Social Affairs (https://www.un.org/development/ desa/dspd/sport-development-peace.html). Moreover, the UN presents sport as a potent instrument on how to cope with various post-Covid-19 issues related to specific SDGs (United Nations 2020).

\section{Other actors active in SDP}

The SDP sector is a very complex field working with a variety of different stakeholders coming from areas of development, peace, sport and many others (Giulianotti 2019). These actors are interrelated on different levels including private, governmental, intergovernmental, non-governmental subjects, various social movements and campaign groups or even individuals with a high level of symbolic capital operating on a local, national, regional or international level (Giulianotti et al. 2016). Historically, the main responsible body was the UNOSDP on the international level substituted by the IOC from 2017 onwards (as described above). Still, several other UN agencies continue to use sport as a tool in their everyday operations (e.g. UNICEF, UNHCR, WHO).

There are many SDP non-governmental organisations (NGOs) working directly in the field on the grass-roots level and are there in touch with the final 
beneficiaries. The SDP projects organised by these NGOs may be based on local participants' needs or, especially when there are other actors involved helping with financing, promotion or coordination, may follow the motives and interests of the involved stakeholders. According to Suzuki (2019), there were 948 SDP organisations registered at the sportanddev.org platform in 2018. This platform is the main communication channel in the area of SDP. The number of SDP organisations started to flower in the 1990s and had its peak in 2008. Currently, the majority of NGOs have their place of origin in Africa (33\%), but the European NGOs implement their activities in a higher number of countries. Suzuki (2019) also describes that there is a general pattern of international geopolitics in SDP NGOs visible between the place of origin and delivery, confirming the North-South relations. European NGOs operate very often in Africa and Asia, while North American ones are in Latin America. However, the South-South and North-North settings also become significant, confirming that there are endogenous practices developed in SDP.

Also, the development banks (as multilateral organisations) have started to harness sport as a tool in their activities. Among them, we can name the Inter-American Development Bank (IDB) that is active mainly in Latin America and the Caribbean. It started with SDP projects in 2004 and focuses on the topics of youth development, youth and wellness, social inclusion and violence prevention. The IDB implements the SDP projects in cooperation with different stakeholders such as AusAID, Save the Children, Nike Foundation, Microsoft, the NBA and many others (IDB 2020; Jaitman - Scartascini 2017).

Several Global North countries have a long history of using sport within their international development cooperation strategies entering in cooperation with different stakeholders in donor and recipient countries. The longest known cooperation in this field was established between Norway (NORAD - Norwegian Agency for Development) and Tanzania in 1984. At that period, Tanzania was the largest recipient of Norwegian development aid. This assistance was mainly guided by the top-down approach where the Norwegian government, through the Norwegian Confederation of Sports, offered different programs and the Tanzanian government could either accept it or not. Mass sport policy was supported in Tanzania and both used and new equipment was shipped from Norway (Straume - Steen-Johnsen 2010). In the development literature, this top-down approach has been already criticised and, actually, the donor-recipient relationships have been changing in the last 30 years. In 2005, Norway even accepted a special strategy called 'Strategy for Norway's culture and sports cooperation with countries in the South'. This one took into account the then existing MDGs and emphasised closer cooperation with local partners (Norwegian Ministry of Foreign Affairs 2005). Since the 1990s, sport has been already harnessed by even more Global North governments, e.g. Netherlands, Canada (CIDA - Canadian International Development Agency), Australia (AusAid - Australian Aid), Ger- 
many (GIZ - German Agency for International Cooperation) and Switzerland (SDC - Swiss Development Cooperation). For instance, the Dutch Ministry of Foreign Affairs supports the Sportfordevelopment.nl Programme using sport in eight priority countries (e.g. Kenya, Mozambique, Palestinian territories) in close cooperation with the Royal Dutch Football Federation (KNVB), International Sports Alliance (ISA) and Right to Play (RTP). Through CIDA, the Canadian policymakers have been leaders in introducing sport into international development agendas, mainly within the UN system, in the Commonwealth and also in the Francophonie. CIDA started to support the Commonwealth Sport Development Program through NGOs known as Commonwealth Games Canada and Right to Play. Therefore, Canadian sport development cooperation reached, e.g. the Middle East, francophone Africa and the Americas. The official support of SDP by the Canadian government was stopped in 2011. Since then, more focus was given to the national use of sport (Kidd 2013). The German government (GIZ agency) also uses sport as a tool for broader social changes within German development cooperation. GIZ implements a regional program called Sport for Development in Africa (S4DA) and other bilateral SDP projects are carried out in, e.g. Indonesia, Colombia, Morocco and Tunisia. Another interesting example of the use of sport in the international development agenda comes from Cuba. Huish (2011) analysed the Cuban perspective of the use of sport within international cooperation. Despite Cuba being part of the Global South, it is very active in sending its sport coaches (and also doctors) to other developing countries to help build community-based sport programs and lead elite performance training. It also offers free scholarships to study sport and physical education in Cuba's leading sport institute on the condition that they go back to their home country after graduation. In this case, Huish (2011) explains this Cuban policy as a way to achieve further recognition, to build partnerships and to use its soft power, e.g. in lobbying for further support of international economic negotiations. On the other side, there are governments of the Global South countries that have also started to put sport into their official development documents. Among such examples, there is the Poverty Reduction Strategy Papers (PRPS) of, e.g. Mozambique, Mali, Malawi and Lesotho.

Until today, Central and Eastern European countries have not been harnessing sport in development cooperation as much as the governments of Western Europe and North America. As Havran, Szabó and Máté (2021) remark, the situation in former Eastern Bloc countries has been affected by the decades of communist regime when sport had no autonomy, the civil society did not exist and a major part of the support was given to elite sports. As a result, the non-government sector and autonomous sporting organisation were heavily underdeveloped at the beginning of the 1990s. Šafaříková and Svoboda (2021) mention the case of the Czech Republic where the development of non-governmental subjects has often been opposed even by Czech politicians disapproving of the 
very concept of civil society. Therefore, the tradition in this geographical area is much shorter. The first SDP project that has been supported through the Czech Official Development Assistance (ODA) since 2006 is called 'Football for Development' (FFD). FFD is organised by the Czech NGO INEX-SDA that entered into cooperation with the Kenyan SDP MYSA (one of the oldest NGOs in this field) in 2005. This project uses football to raise awareness about global development issues in the Czech Republic. Members and youth from MYSA came to the Czech Republic to share their experience from Kenya through the organisation of different football tournaments connected to other participatory discussions and artistic events (Šafař́ková 2012). Since then, activities with social and cultural overlaps have become an integral part of programmes operated by INEX-SDA. Moreover, even activities often subsumed into the corporate social responsibility category have entered the sporting field, such as various foundations or charities in ice hockey, basketball or football (Kunz 2020).

Other important actors in this area are currently the transnational corporations (TNCs) that are mainly supporting SDP programs and projects through their corporate social responsibility (CSR) strategies (Levermore 2019) defined as 'the commitment of businesses to sustainable economic development... to improve quality of life' (World Bank 2003 in Levermore 2019). These TNCs can be divided into two types: a) non-sporting companies and b) sporting companies. In the sport for development area, CSR very often takes the form of philanthropy which means that the business financially supports different SDP initiatives. FIFA created the Football for Hope program that works with different NGOs using football as a tool for further development in a range of educational and empowerment initiatives. Nike, through its CSR philanthropic programme, supports, e.g. women empowerment projects in refugee camps in Eastern Africa. Several famous football clubs have their foundations that are also active in the SDP area (e.g. FC Barcelona, Manchester United). Among the non-sporting businesses, there are, e.g. Ferrero, Huawei, Lenovo, Microsoft, Bayer and BP. All the above-mentioned companies' CSR strategies should contribute to social good. However, there have also been criticisms raised about such approaches: Such CSR support is often only short term (Chen et al. 2008) and it aims at helping to offset the negative media image a company might have created (Babiak et al. 2012). In a similar vein, concepts of blue- and greenwashing critically depict efforts of companies to enhance their CSR image by presenting their activities in a distorted way. This may be done by highlighting their environmental-friendly operations which, actually, do not exist (greenwashing; Gatti et al. 2019) or by associating themselves with UN development goals and benefitting from the symbolic value of the UN brand (bluewashing; Berliner - Prakash 2015).

Recently, Giulianotti et al. (2016) highlight the growing importance of new social movements and campaign groups who often form alliances (such as Sport and Rights Alliance) and become an organised and highly visible actor 
in the SDP field (including Play the Game, Transparency International, Football Supporters Europe, Human Rights Watch, etc.). Amongst the reasons for the current activities of the newly emerged actors are the critique of the lack of democracy in sport governance or some controversial hosting of sporting mega-events, support for present global social issues such as refugee crises or a new entry of some NGOs to the SDP field and their collaboration with several established stakeholders (such as Swiss Terre des Hommes).

From the above written, it is visible that SDP is a very diverse area with many different stakeholders that bring into this field their own interests and experience which can create a lot of good but also many controversies.

\section{Leading role of UN: Development goals agenda (MDG and SDG)}

As of the 1980s, human rights issues were proliferating within the development policy. Although its legal force was limited, the UN Declaration on the Right to Development was adopted in 1986 (UN General Assembly 1986). Darnell et al. (2019) observe that amongst the notable issues were the move from individual rights to group rights and the combination of economic growth, democratic governance and fair distribution of income and wealth. In the next years, the UN focused on highlighting human development including the construction of the Human Development Index. Hence, the importance of the status of people's capabilities in assessing a country's level of development that usually depends on economic factors was only emphasised even further. Darnell et al. (2019) summarize that all these activities led to the creation and adoption of a specific agenda calling attention to the link between development and human rights, the Millennium Development Goals, announced by the UN Millennium Declaration (UN General Assembly) in 2000.

The MDG consists of eight goals that spotlight the international cooperation between member states in the following areas: poverty reduction, achievable primary education, gender equality promotion, reducing child mortality, improving maternal health, combating diseases such as HIV/AIDS or malaria, enhancing environmental sustainability and building global partnerships for development. Each goal incorporates several specific targets and detailed indicators presenting exact data from the concerned areas. Neither the MDGs nor the Millennium Declaration mention sports explicitly but set up a road to 'softer' goals where sports could fit in as one of the potential tools to achieve such goals. In 2003, the UN Inter-Agency Task Force on Sport for Development and Peace prepared a report called Sport for Development and Peace: Towards Achieving the Millennium Development that specifically connected each of the MDGs to sport and physical activity. By contrast, MDGs were also targeted by critics emphasising the lack of empirical data or missing specific procedures on how to involve the international community (Darnell et al. 2019). Some authors also 
accentuated the different cultural and economic context and, thus, the need to focus on local settings of sports as a vehicle for change (Pawlowski et al. 2018).

After 15 years of implementation and observation of results of the MDGs agenda, an updated direction was announced in 2015. A broader set of goals, Sustainable Development Goals, was adopted as a part of the 2030 Agenda for Sustainable Development (UN General Assembly 2015). The document now contains seventeen goals covering a broader scope of objectives including economic, social and environmental issues and governance, this time with a clearly expressed expectation that all governments will attempt to reach the goals adapted to their context. Contrary to MDGs, the SDGs agenda aims not only at developing countries but at all the governments, civil society and business actors. Also, a resolution of the UN General Assembly briefly mentions the potential of sport to foster 'tolerance and respect and the contributions it makes to the empowerment of women and of young people, individuals and communities as well as to health, education and social inclusion objectives' (UNDP 2015: 10/35). It is for the first that sport is recognised as 'an important enabler of sustainable development' (UNDP 2015: 10/35) within the global development agenda (Dudfield 2019).

To examine possible goals where sport might play a substantial role, several expert discussions took place. Amongst others, the following goals were identified as especially cost-efficient by the Commonwealth Advisory Body of Sport in the document entitled Sport for Development and Peace and the 2030 Agenda for Sustainable Development: promoting health and well-being (Goal 3), inclusive and equitable education and lifelong learning (Goal 4), gender equality and women's empowerment (Goal 5), sustainable economic growth, employment and decent work for all (Goal 8), inclusive and safe human settlements (Goal 11) and inclusive societies with access to justice and effective institutions for all (Goal 16). Throughout additional discussions, Goal 17 (strengthening of global partnerships for development) was added as a cross-sectional theme (Dudfield et al. 2015).

In addition to attempts to include SDG into the current SDP mainstream, several papers also emerged critically analysing the link between SDGs and sport in the context of development (Lindsey et al. 2020; Lindsey - Darby 2019). Amongst the questioned topics is the coherence of policies promoting SDGs in connection to SDP. The interrelated links between goals further complicate clearly and comprehensively established policy of how to reach these goals. Still, in contrast to MDGs, SDGs promote policies coordinated at the national level and, therefore, are able to reflect on the local needs. Here, such policy meets the current critical stream in the SDP discourse warning against the dominance of top-down approach to SDP initiatives when local projects are unilaterally designed by foreign powerful donors (Black 2017; Nols et al. 2019). Lindsey and Darby (2019) note that while the sustainable development policies linked 
with sports need to maintain the general coherency, also practical feasibility, gathering the evidence and analysis of local contact must be accentuated.

\section{Contested issues in international SDP}

Taking into account the last fifteen years, the sport for development field arouses a number of critiques concerning locations where SDP initiatives take place and, at the same time, locations where donors and initiators reside. Furthermore, the lack of data confirming the results of SDP interventions is criticised as well as its missing a comprehensive, systematic theoretical framework that could seize the SDP and build an explanatory and understanding model around its activities. Also, the post-colonial heritage is often mentioned as having an impact on today's setting of the SDP field and the positions of stakeholders in it. In the following section, we will briefly delineate the topics just mentioned.

\section{Unequal distribution of SDP activities around the world}

Concerning the general picture of SDP topics in academic journals, one of the most extensive reviews was done by Schulenkorf, Sherry and Rowe in 2016. The authors conducted an integrated literature review using a detailed set of keywords and inclusion criteria. According to the authors, their findings further affirm a substantial contrast between local and international practitioners within SDP programmes. Precisely, $50 \%$ of the persons active in practical or research activities in the SDP field are 'international experts', people coming from countries foreign to the country where a project is carried out (Schulenkorf et al. 2016).

Correspondingly, the total majority ( $92 \%$ ) of academics publishing papers or books about SDP topics reside in countries of the Global North (North America, Europe and Australia). By contrast, over $20 \%$ of studies were placed in the Global South countries and more than $50 \%$ of all the SDP projects are also implemented there. As Schulenkorf et al. (2016) warn, the vast number of projects or topics linked to the SDP in the Global South countries remain without the attention of mainstream research and academic institutions from high-income countries.

\section{Fragmentation of theoretical frameworks}

As Schulenkorf et al. (2016) propose in their integrative review, the SDP field is built on various theoretical sources which are, however, not SDP-specific and are rather borrowed from other disciplines. Amongst other remarks, the authors come up with an interesting observation. Offering the concept of 'so- 
cial capital' as an example, they criticise it as being sometimes 'a last resort' for authors who cannot create a more comprehensive theoretical anchor for their studies. In other words, the concept is too wide and non-transferable between social contexts but, still, it is uncritically used by many SDP authors. Certainly, one of the reasons can be an underdeveloped theory able to frame SDP studies. Nonetheless, the same authors mention several concepts or theories which they found as being commonly used in their review: role models in SDP programmes, participatory approaches, safe spaces in the developing community or sustainable activities transferring experience to local communities (Schulenkorf et al. 2016).

Proponents of the last-mentioned conception, Lyras and Peachey (2011), made a huge effort to construct an SDP theory that is robust and, simultaneously, specific to the SDP field. Such a theory should contain the following components: impact assessment, organisation of activities, sport disciplines with strong development potential, education and cultural enrichment. Summarising the recent development of the SDP field, Giulianotti et al. (2019) bring up several other key points which should be incorporated into new theories tailored to SDP's needs: critical stance, reflexivity of human agency and social transformation, co-creation of development programmes together with local actors and collaboration between critical theory and pragmatic research. Last but not less important, we argue that critical notes suggesting that the above-mentioned ambiguities can be an outcome of the lack of clarity and organisation of the SDP field itself should be considered (see Whitley 2019).

\section{A priori positive effects of sport}

One of the critically remarked characteristics of sport is the supposed positive, beneficial effect it might have on its target groups. Such thoughts follow a positivist and functionalist discourse where sports activities are assigned with an uncritical status concerning their impacts and potential to instigate any change. But, as Darnell (2012) notes, this discourse is not a fact but, rather, a subject of interpretation that is reductive in its nature. Coakley (2011) adds that the neoliberal representations of sports programmes which undoubtedly lead to personality development, dominant values acquisition and civic engagement are supported by mainstream global media with origins in the Global North, Euro-American culture.

Darnell (2012) concludes that without reflecting on situated conditions and local context, there is no possibility to generalise the potential of sport for meeting development or other goals. In other words, the positive effects of SDP are not essential but have to be measured and evaluated accordingly to the current settings. 


\section{Need for evaluation}

As we just remarked, there exists a strong call for systematic and regular evaluation of the coherence between SDP projects' intended and real achievements. Several authors note that many of the current evaluative procedures of SDP projects might be designed to search for the supporting evidence only and, therefore, lacking clearly elaborated objectives or missing local staff taking part in the evaluation (Giulianotti et al. 2019). While such criticising debates are held mostly in academia, Bardocz-Bencsik and Doczi (2019) mention that one of the reasons for the inadequate evaluation may be the crucial importance of continuous access to grants and subsidies for the practitioners in the field.

To sum up, as Giulianotti et al. (2019) remind, a general approach to the evaluation process has to be shaped with a strong reflection on the sport as a broad context for the developmental goals and not as a clearly defined independent variable with a causal effect on the participants. A so-called 'realist evaluation' incorporates context information and theories guiding employed mechanisms and evidence-based outcomes. In this vein, a specific measure is valid in a specific context and for specific beneficiaries. Especially, active interventions of donors should be prevented in favour of local practitioners (Levermore - Beacom 2012). Nicholls, Gilda and Sethna (2011) argue that the research and evaluation should take into consideration more local voices directly from the field.

\section{Hegemony and post-colonialism}

The last presented stream of criticism is rather multifaceted, ideology-driven and extensively benefits from the conceptualisation of global power relations. As regards this paper, we reduce the criticism to the hegemony theory (Darnell 2012) and postcolonialism (Darnell - Hayhurst 2012). The hegemony theory is based on the ideas of Antonio Gramsci illustrating ways the dominant ideology gains ground in practical, day-to-day life. In parallel, the development role of sport is constructed and negotiated through interactions of actors from this fields of sport, culture, politics, media or education. In the last twenty years, the traditional hegemony concept has been broadened with the post-hegemony approach. Following the postmodernist turn, its proponents suggest that the very possibility of detecting the process of domination and consent is almost unreachable because of the unstable and fluid nature of current power and ideologies. Yet, even the traditional essence of sports which is often reproduced within the class structure where the dominant groups secure their status quo should not be overlooked while reflecting on the current complexities of culture (Darnell 2012).

The postcolonial theory rests on the cultural geography background. As of the 1970s, various voices could have been heard highlighting the cultural heritage of 
the colonial past. Saavedra (2019) delineates how the colonial heritage strongly affects the current configuration of power, resources or privileges irrespective of the development level of a country. Actually, several approaches underline also the agency of the formerly colonised nations. While adopting numerous strategies to cope with or resist the imported dominant sports, an indigenous nation builds a hybrid form of the sporting discipline (Bhabha 1994) and, thus, appropriates it to the local cultural, social and political context (Fletcher 2011). Currently, various outcomes of the transformation of post-colonial sport can be identified, e.g. promoting indigenous activities into modern sports (lacrosse) or evolving a specific style within the dominant sport, such as Brazilian soccer (Bale - Cronin 2003). However, Darnell et al. (2019) conclude that the newly independent post-colonial countries still feel the necessity of stepping in the existing dominant sporting structures (major international organisations) to fully participate in the development of the modern sport.

\section{Conclusion}

In this paper, we wanted to introduce the Sport for Development and Peace not only as a theoretical concept but also as a topical and vivid field of practices. On the one hand, SDP projects are locally operated throughout the world aiming at various health, social exclusion, conflict, education or gender-related topics at the community level. On the other hand, they are highly acknowledged by international organisations and agencies as a tool for performing various development goals. Especially the inclusion into, first, the United Nations and, later, the Olympic Movement was probably the most visible turn in the SDP field's acquisition of global relevance.

Consequently, we approach SDP not only as a set of specific projects and initiatives but, in the broadest sense and accordance with the current academic SDP production, as a general conception of sport as a tool used for political, cultural, diplomatic or economic reasons. At the same time, we advocate the critical debate questioning the potential of utilisation of sport and its declared benefits present in many SDP programmes. As a central point of such an approach, a comprehensive evaluative analysis of intended goals, employed methods and final outcomes of SDP practices should be incorporated as an inherent part of SDP strategies and programmes on international, regional or local levels. Even the growing body of academic studies in the last fifteen years supports the essential significance of empirical work and evaluation outcomes for further planning in the SDP field. 


\section{References}

Babiak, Kathy - Mills, Brian M. - Tainsky, Scott - Juravich, Matthew (2012): An Investigation into Professional Athlete Philanthropy: Why Charity Is Part of the Game. Journal of Sport Management 26 (2), 150-176.

Bale, John - Cronin, Mike (2003): Introduction: Sport and Postcolonialism, in Bale, J. - Cronin, M., eds., Sport and Postcolonialism, 1-14, Berg.

Bardocz-Bencsik, Mariann - Doczi, Tamas (2019): Mapping Sport for Development and Peace as Bourdieu's Field. Physical Culture \& Sport. Studies \& Research 81 (1): 1-12.

Berliner, Daniel - Prakash, Aseem (2015): “Bluewashing” the Firm? Voluntary Regulations, Program Design, and Member Compliance with the United Nations Global Compact. Policy Studies Journal 43 (1): 115-138.

Black, David R. (2017): The Challenges of Articulating 'Top down' and 'Bottom up' Development through Sport. Third World Thematics: A TWQ Journal 2 (1): 7-22.

Bhabha, Homi K. (1994): The Location of Culture, Routledge.

Busbee, Jay (2013): Nelson Mandela: 'Sport Has the Power to Change the World.', Yahoo!Sports. available at: http://sports.yahoo.com/blogs/the-turnstile/nelson-mandela-sport-power-change-world-215933270.html (1 December, 2020).

Chen, Jennifer C. - Patten, Dennis - Roberts. Robin W. (2008): Corporate Charitable Contributions: A Corporate Social Performance or Legitimacy Strategy? Journal of Business Ethics 82 (1): 131-144.

Coakley, Jay (2011): Youth Sports: What Counts as 'Positive Development?' Journal of Sport and Social Issues 35 (3): 306-324.

Coalter, F. (2010): The politics of sport-for-development. Limited focus programmes and broad gauge problems? International Review for the Sociology of Sport 45 (3): 295-314.

Darnell, Simon (2012): Sport for Development and Peace. A Critical Sociology, Bloomsbury Publishing.

Darnell, Simon C. - Field, Russell - Kidd, Bruce (2019): The History and Politics of Sport-for-Development. Activists, Ideologues and Reformers, Palgrave Macmillan.

Darnell, Simon C. - Huish, Robert (2015): Cuban sport and the challenges of South-South solidarity, in Hayhurst, Lyndsay M. C. - Kay, Tess - Chawansky, Megan, eds, Beyond Sport for Development and Peace: Transnational perspectives on theory, policy and practice, 35-46, Routledge.

Dudfield, Oliver (2019): SDP and Sustainable Development Goals, in Collison, Holly - Darnell, Simon C. - Giulianotti, Richard. - Howe, David P., eds., Routledge Handbook of Sport for Development and Peace, 116-127, Routledge.

Dudfield, Oliver - Dingwall-Smith, Malcolm - Silubonde, Tikwiza (2015): Sport for Development and Peace and the 2030 Agenda for Sustainable Development, Commonwealth Secretariat.

Fletcher, Thomas (2011): The Making of English Cricket Cultures: Empire, Globalization and (Post) Colonialism. Sport in Society 14(1): 17-36. 
Gatti, Lucia - Seele, Peter - Rademacher, Lars (2019): Grey Zone in - Greenwash out. A Review of Greenwashing Research and Implications for the Voluntary-Mandatory Transition of CSR. International Journal of Corporate Social Responsibility 4 (1): 1-15.

Giulianotti, Richard (2011): Sport, Peacemaking and Conflict Resolution: A Contextual Analysis and Modelling of the Sport, Development and Peace Sector. Ethnic and Racial Studies 34 (2): 207-228.

Giulianoti, Richard (2019): The SDP sector, in Collison, Holly - Darnell, Simon C. - Giulianotti, Richard - Howe, David P., eds., Routledge Handbook of Sport for Development and Peace, 24-34, Routledge.

Giulianotti, Richard - Coalter, Fred - Collison, Holly - Darnell, Simon C. (2019): Rethinking Sportland: A New Research Agenda for the Sport for Development and Peace Sector. Journal of Sport and Social Issues 43 (6): 411-437.

Giulianotti, Richard - Hognestad, Hans - Spaaij, Ramón (2016): Sport for Development and Peace: Power, Politics, and Patronage. Journal of Global Sport Management 1 (3-4): 129-141.

Grix, Jonathan - Lee, Donna (2013): Soft Power, Sports Mega-Events and Emerging States: The Lure of the Politics of Attraction. Global Society 27 (4): 521-536.

Hardt, Michael - Negri, Antonio (2000): Empire. Harvard University Press.

Harrison Virginia S. - Boehmer, Jan (2020): Sport for Development and Peace: Framing the Global Conversation. Communication \& Sport 8 (3): 291-316.

Havran, Zsolt - Szabó, Ágnes - Máté, Tuende (2021): Sport and Development in Hungary and the Central and Eastern European Region. The Development of the Leisure Sport Industry, in Tinaz, Cem - Knott, Brendon, eds., Sport and Development in Emerging Nations, 58-76, Routledge.

Huish, Robert (2011). Punching above its Weight: Cuba's use of sport for South-South co-operation. Third World Quarterly 32 (3): 417-433.

ICSSPE (2005): MAGGLINGEN COMMITMENT FOR PHYSICAL EDUCATION, International Council of Sport Science and Physical Education: available at: https://www.icsspe.org/sites/default/files/ Magglingen\%20Commitment\%20for\%20Physical\%20Education_0.pdf (12 February, 2021).

IDB (2020): Sports for Development at the IDB, Inter-American Development Bank: available at: https://www.iadb.org/en/sports (15 March, 2021).

IOC (2015): FACTSHEET. OLYMPIC TRUCE. UPDATE - DECEMBER 2015, International Olympic Committee: available at: https://stillmed.olympic.org/Documents/Reference_documents_ Factsheets/Olympic_Truce.pdf (17 February, 2021).

IOC (2019): Independent research conducted on behalf of the IOC demonstrates global strength of the Olympic values - Olympic News, International Olympic Committee: available at: https:// www.olympic.org/news/independent-research-conducted-on-behalf-of-the-ioc-demonstrates-global-strength-of-the-olympic-values (17 February, 2021).

IOC (2020): Public Affairs and Social Development through Sport, International Olympic Committee: available at: https://www.olympic.org/public-affairs-and-social-development-through-sport (17 February, 2021). 
Jaitman, L. - Scartascini, C. (2017): Sports for Development, Inter-American Development Bank: available at: https://publications.iadb.org/publications/english/document/Sports-for-Development.pdf (15 March, 2021).

Kay, Tess - Dudfield, Oliver (2013): The Commonwealth Guide to Advancing Development through Sport, Commonwealth Secretariat: available at: https://thecommonwealth.org/sites/default/ files/inline/The+CW+Guide+to+Advancing+Sport+EB.pdf (15 March, 2021).

Kidd, Bruce (2008): A new social movement: Sport for development and peace. Sport in Society 11 (4): 370-380.

Kidd, Bruce (2013): Canada and Sport for Development and Peace, in Thibault, L. - Harvey, J., eds., Sport Policy in Canada, 69-94, University of Ottawa Press.

Kofi Annan Foundation (2010): Kofi Annan: We Must Use the Power of Sport as an Agent of Social Change, Kofi Annan Foundation: available at: https://www.kofiannanfoundation.org/ news-releases/kofi-annan-we-must-use-the-power-of-sport-as-an-agent-of-social-change/ (1 December, 2020).

Kunz, Vilém (2020): Společenská odpovědnost ve sportu, Grada Publishing.

Levermore, Roger (2008): Sport: a new engine of development? Progress in Development Studies 8 (2): 183-190.

Levermore, Roger (2009): Sport-in-International Development: Theoretical Frameworks, in Levermore, R. - Beacom, A., eds., Sport and International Development, 26-54, Palgrave Macmillan.

Levermore, Roger (2019): SDP and corporate social responsibility, in Collison, Holly - Darnell, Simon C. - Giulianotti, Richard - Howe, David P., eds., Routledge Handbook of Sport for Development and Peace, 103-115, Routledge.

Levermore, Roger - Beacom, Aaron (2009): Sport and Development: Mapping the Field., in Levermore, R. - Beacom, A., eds., Sport and International Development, 1-25, Palgrave Macmillan.

Levermore, Roger - Beacom, Aaron (2012): Reassessing Sport-for-Development: Moving beyond 'Mapping the Territory'. International Journal of Sport Policy and Politics 4 (1): 125-137.

Lindsey, lain - Chapman, Tony - Dudfield, Oliver (2020): Configuring Relationships between State and Non-State Actors: A New Conceptual Approach for Sport and Development. International Journal of Sport Policy and Politics 12 (1): 127-146.

Lindsey, lain - Darby, Paul (2019): Sport and the Sustainable Development Goals: Where is the policy coherence? International Review for the Sociology of Sport 54 (7): 793-812.

Lyras, Alexis - Welty Peachey, Jon (2011): Integrating sport-for-development theory and praxis. Sport Management Review 14 (4): 311-326.

Millington, Rog - Kidd, Bruce (2019): The history of SDP, in Collison, Holly - Darnell, Simon C. Giulianotti, Richard - Howe, David P., eds., Routledge Handbook of Sport for Development and Peace, 13-23, Routledge.

Nicholls, Sara - Gilda, Audrey R. - Sethna, Christabelle (2011): Perpetuating the 'lack of evidence' discourse in sport for development: Privileged voices, unheard stories and subjugated knowledge. International Review for the Sociology of Sport 46 (3): 249-264. 
Nols, Zeno - Haudenhuyse, Reinhard - Spaaij, Ramon - Theeboom, Marc (2019): Social Change through an Urban Sport for Development Initiative? Investigating Critical Pedagogy through the Voices of Young People. Sport, Education and Society 24 (7): 727-741.

Norwegian Ministry of Foreign Affairs (2005): Strategy for Norway's culture and sports co-operation with countries in the South, Norwegian Ministry of Foreign Affairs.

Nye, Joseph S. (2004): Soft Power. The Means to Success in World Politics, PublicAfairs.

Pawlowski, Tim - Schüttoff, Ute - Downward, Paul - Lechner, Michael (2018): Can Sport Really Help to Meet the Millennium Development Goals? Evidence From Children in Peru. Journal of Sports Economics 19 (4): 498-521.

Saavedra, Martha (2019) SDP and Postcolonial Theory, in Collison, Holly - Darnell, Simon C. Giulianotti, Richard - Howe, David P., eds., Routledge Handbook of Sport for Development and Peace, 208-218, Routledge.

Said, Edward W. (1979): Orientalism, Vintage.

Schulenkorf, Nico - Sherry, Emma - Rowe, Katie (2016): Sport-for-Development: An Integrated Literature Review. Journal of Sport Management 30 (1): 22-39.

Straume, Solveig - Steen-Johnsen, Kari (2010): On the terms of the recipient? Norwegian sports development aid to Tanzania in the 1980s. International Review for the Sociology of Sport 47 (1): 95-112.

Sport en Commun (n.d.): Olympafrica: A programme for African youth, Sport En Commun: available at: https://www.sportencommun.org/en/projects/olympafrica-a-programme-for-african-youth/ (15 March, 2021).

sportanddev.org (2017): A call for action following the closure of the United Nations Office on Sport for Development and Peace (UNOSDP), Sportanddev.Org: available at: https://www. sportanddev.org/en/article/news/call-action-following-closure-united-nations-office-sport-development-and-peace-unosdp (15 March, 2021).

Suzuki, Naofumi (2019): Non-governmental organisations in the SDP system, in Collison, HollyDarnell, Simon C. - Giulianotti, Richard - Howe, David P., eds., Routledge Handbook of Sport for Development and Peace, 70-79, Routledge.

Šafaříková, Simona (2012): Sport a rozvoj - koncept a potenciál pro vzdělávání. Česká kinantropologie 16 (4): 11-28. [Sport and development - concept and the potentials for education].

Šafař́ková, Simona - Svoboda, Arnošt (2021): Sport and Development in the Czech Republic. Sport as a Tool for Social and Cultural Transformation, in Tinaz, C. - Knott, B., eds. Sport and Development in Emerging Nations, 44-57, Routledge.

UN General Assembly (1986): Declaration on the Right to Development, General Assembly Resolution 41/128 of 4 December 1986: available at: https://www.ohchr.org/en/professionalinterest/ pages/righttodevelopment.aspx (3 February 2021).

UN General Assembly (1989): Convention on the Rights of the Child, United Nations: available at: https://www.ohchr.org/EN/Professionallnterest/Pages/CRC.aspx (15 March, 2021).

UN General Assembly (2000): United Nations Millennium Declaration, United Nations: available at: http://undocs.org/A/RES/55/2 (3 February, 2021). 
UN General Assembly (2003): Sport as a Means to Promote Education, Health, Development and Peace, United Nations: available at: https://undocs.org/en/A/RES/58/5 (12 February, 2021).

UN General Assembly (2015): Transforming Our World: The 2030 Agenda for Sustainable Development, United Nations: available at: https://www.un.org/en/development/desa/population/ migration/generalassembly/docs/globalcompact/A_RES_70_1_E.pdf (5 February, 2021).

UNDP (2016): From MDGs to Sustainable Development For All, United Nations Development Programme: available at: https://www.undp.org/content/dam/undp/library/SDGs/English/ From\%20the\%20MDGs\%20to\%20SD4All.pdf (5 February, 2021).

UNESCO (2015): International Charter of Physical Education, Physical Activity and Sport, UNESCO: available at: https://unesdoc.unesco.org/ark:/48223/pf0000235409 (12 February, 2021).

Unites Nations (2006): Report on the International Year of Sport and Physical Education 2005, United Nations.

United Nations (2020): Recovering Better: Sport for Development and Peace Reopening, Recovery and Resilience Post-COVID-19, United Nations: available at: https://www.un.org/development/ desa/dspd/wp-content/uploads/sites/22/2020/12/Final-SDP-recovering-better.pdf (10 June, 2021).

Whitley, Meredith A. - Farrell, Kelly - Wolff, Eli A. - Hillyer, Sarah J. (2019): Sport for Development and Peace: Surveying Actors in the Field. Journal of Sport for Development 7 (12): 1-15.

Arnošt Svoboda is an Assistant Professor at the Faculty of Physical Culture, Palacký University Olomouc/Czech Republic. He is a sociologist with a research interest in the cultural role of sport in society, sport for development and sporting subcultures. E-mail:arnost.svoboda@upol.cz.

Simona Šafařiková works as an Assistant Professor at the Department of Development Studies, Faculty of Science, Palacký University Olomouc/Czech Republic. She focuses her research on the topic of sport for development and has been involved in projects all around the world. She is a member of the Advisory Board of the International Sociology of Sport Association. E-mail: simona.safarikova@upol.cz. 